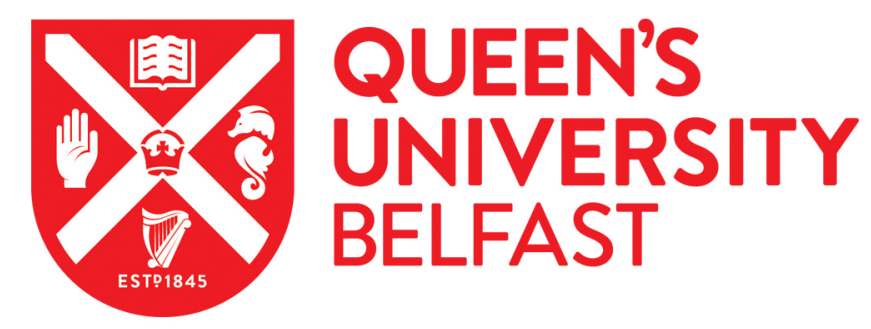

\title{
Gender and the Politics of Shame: A Twenty-First-Century Feminist Shame Theory
}

Fischer, C. (2018). Gender and the Politics of Shame: A Twenty-First-Century Feminist Shame Theory. Hypatia: A Journal of Feminist Philosophy, 33(3), 371-383. https://doi.org/10.1111/hypa.12431

Published in:

Hypatia: A Journal of Feminist Philosophy

Document Version:

Peer reviewed version

Queen's University Belfast - Research Portal:

Link to publication record in Queen's University Belfast Research Portal

Publisher rights

Copyright 2018 CUP. This manuscript is distributed under a Creative Commons Attribution-NonCommercial-NoDerivs License

(https://creativecommons.org/licenses/by-nc-nd/4.0/), which permits distribution and reproduction for non-commercial purposes, provided the author and source are cited.

\section{General rights}

Copyright for the publications made accessible via the Queen's University Belfast Research Portal is retained by the author(s) and / or other copyright owners and it is a condition of accessing these publications that users recognise and abide by the legal requirements associated with these rights.

Take down policy

The Research Portal is Queen's institutional repository that provides access to Queen's research output. Every effort has been made to ensure that content in the Research Portal does not infringe any person's rights, or applicable UK laws. If you discover content in the Research Portal that you believe breaches copyright or violates any law, please contact openaccess@qub.ac.uk. 


\section{Gender and the Politics of Shame: A Twenty-first Century Feminist Shame Theory}

\section{By Clara Fischer}

Conceiving of 'Gender and the Politics of Shame'

This special issue explores the relevance of shame to feminist theory and practice. Across a number of contexts, theoretical frames, and disciplines, the articles collated here provide a stimulating engagement with shame, posing questions and developing analyses that have a direct bearing on feminism. For, the significance of shame to feminists lies in the complex and often troubling implications it holds as a feeling that may be experienced differently by people of certain genders (and none), and in its relation to power. Indeed, as the contributions to this special issue highlight, shame may play a role in our moral development, but given its often readily acknowledged harmful effects, shame is frequently put to politically problematic and morally questionable ends. In patriarchal societies the outgrowths of this regularly entail gendered consequences, as gendered shame may form a disciplining device operating through structures of oppression, such as gender, but also class, race, ethnicity, sexuality, nationality, and related intersectional categories. The question of a politics of shame therefore arises in the context of a consideration of the social and political deployment and manipulation of shame, and the reported divergence in the shame experience itself, which feminists have attributed to its manifestation through, among others, gender.

In following Spelman's comments on there being "a politics of emotion," which she outlines with regard to anger, I maintain, and the authors of this issue persuasively illustrate, that there is a politics of shame, which similarly involves gendered subordination and insubordination. ${ }^{1}$ When conceiving of the proposal for this special issue, then, one of its primary envisaged aims was to establish and thoroughly interrogate this politics of shame and its connection to gender. I am pleased to say that the contributions to the issue have exceeded my expectations in this regard, drawing out many of the complexities involved in theorizing this difficult topic of the relation between gender, power, and shame. Work on shame can be challenging, not least because of the "slipperiness" of shame, which makes identifying, defining, and analyzing this feeling a necessarily inexact science, but also because of the affective toil it may take on the researcher. Shame is, notoriously, a painful emotion, and a sustained engagement with shame - even if this is at an academic, scholarly "remove" - can leave one vulnerable, even hurt, in its wake. This makes me appreciate, all the more, the work and affective effort contributed by the authors in their respective philosophical investigations of shame presented here.

The second motivator for the special issue on 'Gender and the Politics of Shame' lay in the conspicuous absence of such a collation of essays in a feminist academic journal. Although there were already some important examples of feminist scholarship on shame (some of which will be discussed below), a systematic journal

\footnotetext{
${ }^{1}$ The relevant passage in Spelman's text is: "there is a politics of emotion: the systematic denial of anger can be seen in a mechanism of subordination, and the existence and expression of anger as an act of insubordination" - Elizabeth V. Spelman, "Anger and Insubordination," in Women, Knowledge, and Reality: Explorations in Feminist Philosophy, ed. Ann Garry and Marilyn Pearsall (Boston: Unwin Hyman, 1989), 263-73, 270.
} 
collection on the theme was, until now, sadly missing. ${ }^{2}$ Hence, in light of the strong linkages between gender and shame already identified in existing feminist work, it seemed, to me, an oversight that needed to be redressed. Following a surprisingly popular conference on the theme, ${ }^{3}$ which formed part of a British Academy-funded fellowship on 'The Politics of Shame: Containment, Gender, and Embodiment' ${ }^{4}$ I felt sufficiently bolstered and compelled to submit a proposal on an important, but hitherto under-examined theme. The result is, I think, a rewarding and unique set of essays that meets my two aims of establishing and examining the gendered politics of shame, and ameliorating the lack of a dedicated, feminist scholarly space reserved for doing so. 'Gender and the Politics of Shame' thus hopes to form a productive and lasting resource to consolidate shame as a topic with deep and persistent significance for feminists, articulating a distinctly feminist shame theory that draws on current trends in feminist thought, as well as on feminist canonical expositions of gendered shame.

Situating Gendered Shame in Contemporary Trends in Feminist Thought The work featured in this special issue must be understood in the wider context of current developments in feminist thought. Notably, what has been termed a "turn to affect" has prompted a critical, feminist engagement with work on feeling while spawning feminist analyses focused particularly on the promise of affect for metaphysical questions beyond social constructionism and deconstruction. ${ }^{5}$ The affective turn and the related turn to materiality - which, together, I deem characteristic of a "new school" of feminism made up of affect theorists and new materialists $^{6}$ - highlight ongoing concerns with materiality and the body, affect and emotion, and generally present feeling-states as embodied phenomena. This emphasis on embodied feeling, in particular, is conducive to analyses of shame, as shame is often described in terms of that most telling of bodily responses - the blush ${ }^{7}$ - and, indeed, several authors have drawn on affect theory to theorize shame in their contributions to this special issue.

In addition to this, some recent, important feminist work on shame has been emerging, including monographs that add to the sporadic, but notable, examples of feminist theoretical work on the topic. Jill Locke's book, Democracy and the Death of

\footnotetext{
${ }^{2}$ Since the publication of the Hypatia call for papers another journal, Feminism \& Psychology, put out a call for a special issue on 'A Politics of Shame' to be published in 2019. This underlines the attractiveness of and the need for greater engagement with the topic of shame as it relates to feminism. ${ }^{3}$ A Facebook event page for the conference gained thousands of followers, which presented its own quandary given the necessarily limited space and resources available for such a gathering. It nonetheless highlighted the strong interest in the topic, and filled me with further belief in the desire and need for a sustained treatment of gender and the politics of shame.

${ }^{4}$ For further details, see www.gendershame.com.

${ }^{5}$ For a more detailed discussion of the role of affect and emotion in feminist thought and the current phenomenon of the affective turn, see Clara Fischer, "Feminist Philosophy, Pragmatism, and the "Turn to Affect': A Genealogical Critique," Hypatia: A Journal of Feminist Philosophy 31, no. 4 (2016): 810-26. For examples of work done by affect theorists, see Patricia T. Clough, "The Affective Turn: Political Economy, Biomedia, and Bodies," in The Affect Theory Reader, ed. Melissa Gregg and Gregory J. Seigworth (London: Duke University Press, 2010), 206-25. Melissa Gregg and Gregory J. Seigworth, eds., The Affect Theory Reader (London: Duke University Press, 2010).

${ }^{6}$ Clara Fischer, "Revisiting Feminist Matters in the Post-Linguistic Turn: John Dewey, New Materialisms, and Contemporary Feminist Thought," in New Feminist Perspectives on Embodiment, ed. Clara Fischer and Luna Dolezal (Palgrave MacMillan, 2018).

${ }^{7}$ Notably, see Elspeth Probyn, Blush: Faces of Shame (London: University of Minnesota Press, 2005).
} 
Shame, ${ }^{8}$ reviewed in this special issue, is an example of this, as is Luna Dolezal's The Body and Shame. ${ }^{9}$ Shame seems also to have captured the imagination of scholars working in related, critical scholarly areas, including in cultural studies, political theory, and critical race theory, again, with prominent recent works by Christopher J. Lebron (The Color of Our Shame) and Myra Mendible (American Shame) reviewed as part of this special issue. ${ }^{10}$ The timeliness of 'Gender and the Politics of Shame' is therefore not in doubt, as the special issue showcases new and original work on shame at that very moment evincing a contemporary, nascent interest in shame's potential for social and political analysis, advanced by critical theorists working across the disciplines on shame, but also on affect and emotion more generally. The contributions collated here thus reinforce the current, invigorated theoretical engagement with feeling, and solidify shame's status as a topic that can be fruitfully explored by feminists and critical theorists in a variety of fields.

\section{Contextualizing 'Gender and the Politics of Shame' Through Existing Feminist Work on Shame}

While it is important to point to these contemporary trends that have recently seen some theorists preoccupied with shame and, to a greater extent, with the political purchase of feelings as such, one must also be careful here not to elide earlier, pioneering work on emotion, as well as on shame. ${ }^{11}$ There is a long-standing feminist interest in the affective dimension of our lives, with theories and analyses developed to ascertain how social, political, epistemological, and metaphysical questions can be addressed when one takes emotions and affects seriously. ${ }^{12}$ This includes a specific albeit, as noted, sporadic - feminist canonical focus on shame, in relation to which this special issue positions itself. One influential example is Simone de Beauvoir's The Second Sex, which already outlined the close relationship between embodiment and shame as experienced by the girl child, and detailed the pained experience of shame during puberty. Noting the importance of "social context," Beauvoir points to the significance of gendered social meanings attached to the different experiences of

\footnotetext{
${ }^{8}$ Jill Locke, Democracy and the Death of Shame: Political Equality and Social Disturbance (Cambridge University Press, 2016).

${ }^{9}$ Luna Dolezal, The Body and Shame: Phenomenology, Feminism, and the Socially Shaped Body (London: Lexington Books, 2015).

${ }^{10}$ Christopher J. Lebron, The Color of Our Shame: Race and Justice in Our Time (New York: Oxford University Press, 2013). Myra Mendible, ed., American Shame: Stigma and the Body Politic (Bloomington: Indiana University Press, 2016).

${ }^{11}$ Given the constraints posed by an introduction such as this, what follows will not be an exhaustive account of shame in the relevant disciplines, nor even in feminist theory, but will merely be a highlighting of some existing, important work on shame in relation to which the special issue positions itself.

${ }^{12}$ A more detailed discussion can be found in Fischer, "Feminist Philosophy, Pragmatism, and the 'Turn to Affect': A Genealogical Critique." For prominent examples of existing work on emotion, see the Spelman chapter already mentioned, Spelman, "Anger and Insubordination," as well as: Elizabeth V. Spelman, "The Virtue of Feeling and the Feeling of Virtue," in Feminist Ethics, ed. Claudia Card (Kansas: University of Kansas Press, 1991), 213-32. Alison Jaggar, "Love and Knowledge: Emotion in Feminist Epistemology," in Women and Reason, ed. Elizabeth D. Harvey and Kathleen Okruhlik (Ann Arbor: The University of Michigan Press, 1992), 115-42. Diana Tietjens Meyers, "Emotions and Heterodox Moral Perception: An Essay in Moral Social Psychology," in Feminists Rethink the Self, ed. Diana Tietjens Meyers (Boulder, CO: Westview Press, 1997). Audre Lorde, "The Uses of Anger: Women Responding to Racism," in Sister Outsider: Essays and Speeches (Berkeley: Crossing Press, 1984), 124-35. See also the recent special issue of this journal on Feminist Love Studies, Ann Ferguson and Margaret E Toye, "Special Issue: Feminist Love Studies," Hypatia: A Journal of Feminist Philosophy 32, no. 1 (2017).
} 
adolescent development, which, for the girl, establish menstruation as "a curse." the symbol of femininity, "and because femininity signifies alterity and inferiority," menstruation's "manifestation is met with shame." 14 Beauvoir's work brings together themes that continuously resurface in feminist theorizations of shame: the relation of shame to femininity, the body, women's sexualized bodies, and power. Forming a sort of feminist Leitmotif of shame, these themes recur not only in important twentieth century feminist thought on shame - Iris Marion Young, for instance, takes up Beauvoir's discussion of shame and menstruation in her essay "Menstrual Meditations"15 - but also find a home in the present issue on "Gender and the Politics of Shame.' In " Domesticating Bodies: Understanding the Role of Shame in Obstetric Violence," Sara Cohen Shabot and Keshet Korem thus explore the operation of shame in a context where gendered bodies are often susceptible to coercive and degrading treatment. For Cohen Shabot and Korem, gendered shame reinforces strict codes of femininity that diminish women's role in the birthing process, sexualize their bodies, and prescribe a self-sacrificial conception of motherhood, thereby effectively erasing birthing women's agency and entitlement to respectful care. As such, Cohen Shabot and Korem maintain that the only way to interrupt the "alliance" between gendered shame and obstetric violence is to "creat[e] new models of femininity and motherhood."

This linkage between gender, the body, and violence is similarly examined by other contributing authors in this special issue. Bonnie Mann distinguishes, in her essay, "Femininity, Shame, and Redemption," between two types of shame: one termed "ubiquitous shame" (which is typical of "feminine existence as such"), the other "unbounded shame" (a more devastating kind that may follow on from ubiquitous shame). By exploring the contemporary phenomenon of "sexting" and the exploitation of adolescent girls' vulnerability in the context of a technologicallydriven "modalit[y] of sexual value-extortion," Mann sets out how ubiquitous shame descends into unbounded shame. In an analysis of the tragic case of Amanda Todd, Mann develops a feminist political phenomenology of shame that sheds light on the contradictory and damaging dynamic between ubiquitous shame, from which adolescent girls seek redemption through "culturally prescribed forms of sexual display," and unbounded shame, perpetuated endlessly through new media, and resulting in the violent, "logical conclusion" of suicide.

Social media are also presented as a platform for the public shaming of feminized and racialized Kurdish populations in Fulden Ibrahimhakkioglu's article, "The Most Naked Phase of Our Struggle": Gendered Shaming and Masculinist DesiringProduction in Turkey's War on Terror." Ibrahimhakkioglu establishes the circulation of violent and threatening images of the conflict in southeast Turkey as an "aesthetic (re)construction of militarized masculinity," and interrogates representations of the masculinist nation-state through the prism of shame and in its relation with gender, race, and ethnicity. For Ibrahimhakkioglu, the sexualized, feminine body is central to the production of a particular masculinity through shaming, but also to the marking of Kurdish bodies as gendered and "racially inferior." Ibrahimhakkioglu counterposes gendered shaming with women's peace activism and the liberatory potential of

\footnotetext{
${ }^{13}$ Simone Beauvoir, The Second Sex (London: Vintage, 1997), 341.

${ }^{14}$ Ibid.

${ }^{15}$ Iris Marion Young, "Menstrual Meditations," in On Female Body Experience: "Throwing Like a Girl and Other Essays" (Oxford University Press, 2005).
} 
"politicized, critical art," which "could offer a retraining of sensibilities," allowing for "new economies of desire" to emerge.

In "Humiliation as a Harm of Sexual Violence: Feminist Versus Neoliberal Perspectives," Dianna Taylor draws on Foucault's account of "the relation of self to self" and work by Margalit and Guenther to differentiate shame from humiliation. By examining the 2012 Steubenville case of the gang-rape of a teenager, Taylor argues that humiliation itself forms a harm of the sexual violence committed against women. Taylor's article constitutes a rare discussion of the relationship between shame and humiliation, and continues the familiar themes of power, embodiment, and feeling (in this case, humiliation, and its effects on how one relates to oneself) that usually also feature as part of the feminist Leitmotif of shame. Assessing recent discussion of "resilience" as a way of dealing with harm, and the attendant individuating, neoliberal framing of sexual violence and risk, Taylor ultimately maintains that, although tempting, resilience does not further feminist projects against sexual violence. Instead, such projects, to her, must form public, shared, inclusive responses of feminist solidarity.

The connection between gender, feeling, and violence has important precedent in feminist work on shame, especially as it pertains to the embodied vulnerability we share - however unequally - as a result of being in this world in certain ways, and the implications this holds for us in societies where embodied vulnerability is negotiated via strict prohibitions on the performance of particular masculinities and femininities. Bonnie Mann's work on "sovereign masculinity" in the context of the "war on terror," for example, sets out the close relationship between the construction of a particular notion of manhood and gendered shaming's role in producing "morally complicit and relatively thoughtless" subjects - that is, subjects who are produced precisely to service "a nation committed to a policy of preemptive war." 16 Via the "shame-topower conversion," Mann's "sovereign man" emerges from being shamed and vulnerable to form a powerful subject integrated into the community of his peers. The conversion involves the spectacle of violence, or at least threatened violence, as it requires "a visible sign of the victim's vulnerability and the sovereign man's power." 17

Similar theorizations of shame in the context of the nation and the transgression of strictly policed gender and sexual norms can also be found in my own work. In "Gender, Nation, and the Politics of Shame: Magdalen Laundries and the Institutionalization of Feminine Transgression in Modern Ireland," I've explored Ireland's pervasive system of institutionalization in terms of gendered shame and the formation of a post-colonial national identity that depended on the stringent enforcing of a femininity of moral, sexual purity. The mass-institutionalization of gendered Others in Ireland was thus reflective of a politics of shame that excised transgressive women and children to satisfy the demands of a national imaginary in which Irish identity was premised on the superior virtue of the Irish (and Irish women in particular), when compared to the former colonizer. ${ }^{18}$ In an article published in this

\footnotetext{
${ }^{16}$ Bonnie Mann, Sovereign Masculinity: Gender Lessons From the War on Terror (Oxford: Oxford University Press, 2014), 117.

${ }^{17}$ Ibid, 125.

${ }^{18}$ Clara Fischer, "Gender, Nation, and the Politics of Shame: Magdalen Laundries and the Institutionalisation of Feminine Transgression in Modern Ireland," Signs: Journal of Women in Culture and Society 41, no. 4 (2016): 821-43.
} 
journal, “'Revealing Ireland's 'Proper' Heart: Apology, Shame, Nation," I trace this politics of shame to the present day in an analysis of the Taoiseach's (Irish Prime Minister's) recent apology to Magdalen laundry survivors. I show that the state apology, while proclaiming national self-assessment and regret, again involves that classic mechanism of shame, hiding, to present Ireland as a morally progressive, magnanimous nation while covering the contemporary shaming of single mothers. ${ }^{19}$ In her book, Queer Attachments: The Cultural Politics of Shame, Sally Munt previously also examined ideas of the nation, and how such ideas relate to Irishness, shame, and homophobia in New York's St. Patrick's Day Parades. Munt's work, more generally, is an important example of the queering of shame, as she examines "the shame habitus, embodied in the subcultural histories of the poor, the queer, and the Irish Catholic diaspora." 20

On foot of the notable collection, Gay Shame, edited by David Halperin and Valerie Traub; ${ }^{21}$ Michael Warner's The Trouble with Normal;22 Bogdan Popa's recent Shame: A Genealogy of Queer Practices in the $19^{\text {th }}$ Century $;^{23}$ and Judith Butler's articulation of shame as the product of "the stigma... of queerness," ${ }^{24}$ contributors to this special issue also explore shame in relation to the heteronormative circumscription of desire and queer sexual relationships. In "Sunsets and Solidarity: Overcoming Sacramental Shame in Conservative Christian Churches to Forge a Queer Vision of Love and Justice," Theresa Tobin and Dawne Moon draw on their qualitative study of LGBTI conservative Christians to develop the concept of "sacramental shame." This type of shame, "dispens[ed]...as a sacrament," poses as love and comes with the continuous demand for a proving of shameful self-denial or repentance in order to avoid the severing of community bonds. As Tobin and Moon put it: "it makes being recognized as a person - in the eyes of God and others - contingent on constant displays of the will to change... instilling shame as an enduring, conscious mental state." For LGBTI conservative Christians to emerge from this, Tobin and Moon recommend a "nonhubristic, communitarian pride."

Emma McKenna's article, ““"Everything Being Tangled Up In Every Other Thing”: Class, Desire, and Shame in Michelle Tea's The Passionate Mistakes and Intricate Corruption of One Girl in America" provides an analysis of the third chapter of Tea's text to draw out how shame figures in the life-writing of a queer, working-class woman author. McKenna examines the potentially productive nature of shame through a reading of how class and desire reinforce each other in Tea's memoir and builds upon a theorization of shame advanced by queer, feminist, and affect theorists. Described by McKenna as a "catalogue of love and labor," Tea's work brings to the fore the complex entanglements between "desire, identity, shame, and class." This is particularly evident in her discussion of the text's treatment of sex work and the

\footnotetext{
${ }^{19}$ Clara Fischer, "Revealing Ireland's 'Proper' Heart: Apology, Shame, Nation," Hypatia: A Journal of Feminist Philosophy 32, no. 4 (2017): 751-67.

${ }^{20}$ Sally R. Munt, Queer Attachments: The Cultural Politics of Shame (Aldershot: Ashgate, 2008), 16.

${ }^{21}$ David Halperin and Valerie Traub, eds., Gay Shame (Chicago and London: University of Chicago Press, 2009).

${ }^{22}$ Michael Warner, The Trouble with Normal: Sex, Politics, and the Ethics of Queer Life (Cambridge, Mass.: Harvard University Press, 2000).

${ }^{23}$ Bogdan Popa, Shame: A Genealogy of Queer Practices in the 19th Century (Edinburgh: Edinburgh University Press, 2017).

${ }^{24}$ Judith Butler, Bodies That Matter: On the Discursive Limits of "Sex" (New York: Routledge, 2014), 233.
} 
stormy, even abusive, relationship Tea had with a bisexual woman, Liz. McKenna argues that Tea's writing - and the writing of shame - can itself be viewed as transformative, as memoir involves the translation of private experiences into public ones.

Several other contributors to this special issue also focus on how shame features in particular artworks to examine the politico-aesthetic work shame, or indeed art, can or cannot - do. In "Free Lunch with the Stench Wench: Towards a Synaesthetics of Poverty and Shame in Katherine Hoffman's Performance," Alexandra Kokoli continues the theme of classed shame by exploring Hoffman's provocative performance art. Kokoli vividly describes some of the scenes Hoffman sets: a dead rat presented by mouth, cat-like, to the audience; the donning of "austerity pants;" and the reappearance of the rat in hot chocolate, to name but a few. For Kokoli, the symbolic value of props such as the rodent lies in the associations they evoke in audience members, arguing that "the rat, infestation and deprivation...this was the (perceived) stench of poverty." Kokoli thereby interprets Free Lunch as "a synaesthetic portrait of poverty and its psychosocial fallout." Following Hoffman's insistence that the shameful stories of poverty revealed in the performance are not unique, "but the experience of millions in Britain" (Hoffman), Kokoli makes the case for "re-weaponis[ing] shame" against those who first "inflict it," and points to "the failure to make a connection" as a potentially shameful failure in creative work as such.

Robert Shane's article, ““I l longed to cherish mirrored reflections...” Mirroring and Black Female Subjectivity in Carrie Mae Weems's Art against Shame," provides an in-depth reading of four photographs by the renowned visual artist, Carrie Mae Weems. Shane interrogates Weems's "tactical use of mirrors to counter shame" and draws on work by Kelly Oliver, Helen Block Lewis, and bell hooks, to draw out how "the mirror, shame, and black female subjectivity" are configured in Weems's art. Shane explains that Weems presents and confronts racist and sexist depictions of black women's bodies, and the shame such depictions usually rely on. By developing alternative, "counter-hegemonic images" involving mirrors as "a visual metaphor," Weems, according to Shane, rejects the racialized and gendered shame attendant in representations of African American women. Moreover, given the linkage of mirroring to the development of subjectivity and to shame itself - which is often understood to entail an imagined onlooker in whose eyes one is revealed as shameful - Shane shows that Weems asserts an alternative black female subjectivity that rejects shame "as a way of seeing the self" and instead develops "a way of seeing the self lovingly."

The role of mirroring in the shame experience is also taken up by Kimberly Love in "Too Shame to Look: Learning to Trust Mirrors and Healing the Lived Experience of Shame in The Color Purple." Love notes that "mirrors, in the history of black people's lives, have been used to obstruct the formation of affirmative racial identities," with shame constituting, in Tomkins' words, a "sickness of the soul." For Love, Alice Walker, author the The Color Purple, addresses such racialized shame by facing it head-on, that is, by "look[ing] back into the mirror" and "fac[ing] collective shame at the risk of further humiliation in order to achieve wholeness." In an exploration of the aesthetic, epistolary structure of Walker's text, Love draws on Sartre's existentialism and theories of emotion to examine Celie's (the main 
character's) development of self-consciousness, which ultimately issues in Celie's refusal to look away from the mirror. Love frames her essay by situating the analysis of The Color Purple in the wider context of an imagining of a "love ethic for the building and sustaining of communities" to counter racialized shame, which she considers at the time of the novel's publication during the Cosby/Raegan years.

These innovative articles on shame's representation in art, and art's potential to interrupt or reconfigure shame in some way, stand against a backdrop of existing feminist work on shame and aesthetics. Feminists have examined shame in its relation to art with contributions ranging from topics such as feminist shame in the reading of romance novels ${ }^{25}$ to the role of shame in feminist and queer film. ${ }^{26}$ Moreover, Love's and Shane's articles in this special issue should be viewed in the wider context of existing feminist scholarship examining shame at the intersection of race and gender. A prominent example of this is Melissa Harris-Perry's Sister Citizen: Shame, Stereotypes, and Black Women in America, which asserts that "blackness in America is marked by shame," ${ }^{27}$ and sets out how this manifests itself specifically in its interrelation with gender in the lives of black women. By examining various stereotypes, including the Jezebel, Mammy, and Sapphire tropes, Harris-Perry shows that the shaming of black women has distinct consequences for black women's citizenship in the United States. Similarly, bell hooks has pointed to stereotypes and "the fact that from slavery to the present day we are likely to be portrayed as mammies, whores, or sluts" to argue for a "liberatory, black female body politics" that resists sexist, white supremacist shaming of black women's bodies. ${ }^{28}$

All of the essays presented here grapple with the question of what shame is: how it manifests itself, how it is mobilized, performed, felt, experienced - across different contexts, bodies, images, and texts. Authors draw on prominent feminist definitions or develop their own conceptualizations of shame in order to shed light on how we ought best to think about shame and the different feelings, sensations, and thought processes it might involve, and to what extent it intersects with gender and (inter)related structures of oppression. One feminist canonical exposition of shame that is constantly returned to throughout the special issue is Sandra Bartky's formulation of shame, which, according to her, is experienced by women as a "pervasive, affective attunement to the social environment." 29 Mann's "ubiquitous shame" takes its cue from this definition, as does Cohen Shabot and Korem's understanding of gendered shame in relation to obstetric violence. Bartky's work on shame also features in Gail Weiss's contribution to this special issue, "The Shame of Shamelessness." In developing the concept of "secondhand shame," Weiss draws on Bartky, but also on Sartre, Fanon, and Tomkins, to examine whether shame can be felt vicariously, that is, on behalf of somebody else. Specifically, Weiss sets out to show that shame may

\footnotetext{
${ }^{25}$ Hannah Eisler Burnett, "Shame Game: Romance Novels and Feminist Shame, a Mad Lib for Collective Feeling," Women and Performance: A Journal of Feminist Theory 23, no. 1 (2013): 140-44.

${ }^{26}$ Liza Johnson, "Perverse Angle: Feminist Film, Queer Film, Shame," Signs: Journal of Women in Culture and Society 30, no. 1 (2004): 1361-84.

${ }^{27}$ Melissa V. Harris-Perry, Sister Citizen: Shame, Stereotypes, and Black Women in America (New Haven and London: Yale University Press, 2011), 109.

${ }^{28}$ bell hooks, "Naked Without Shame: A Counter-Hegemonic Body Politic," in Talking Visions: Multicultural Feminism in a Transnational Age, ed. Ella Shohat (New York: MIT Press, 2001), 65-74, 67.

${ }^{29}$ Sandra Lee Bartky, "Shame and Gender," in Femininity and Domination: Studies in the Phenomenology of Oppression (New York: Routledge, 1990), 83-98.
} 
be experienced precisely when another person acts shamelessly. Assessing the moral and political implications of the gendered and racialized "displacement of shame," Weiss ultimately argues that "secondhand shame" has the potential to transform through its shared, community-building capacity, a phenomenon Weiss identifies in the large, coalitional resistance "of millions of outraged and ashamed Americans" and "concerned citizens from all over the world" to the shamelessness of Donald Trump.

The final article contribution to this special issue continues the theme of feeling shame on behalf of and with another, and returns us, in a mirroring of Cohen Shabot and Korem's opening article, to questions of motherhood and embodiment. In "Shatter not the Branches of the Tree of Anger: Mothering, Affect, and Disability," Susan Gabel explores the mobilization of shame against non-normative bodies, and her experience of mothering disabled children. In a highly creative intervention, Gabel presents a first-person account of shaming encounters with ableist social and economic structures in a sharing of her affective Story, which is prompted by the common opener of "I have a friend who..." to allow her to "break her silence." Gabel's paper utilizes critical disability theory, feminist theory, Foucault's work, and literary devices to highlight the construction of disabled children and their mothers as shameful. Her contribution examines competing conceptions of motherhood that are affectively produced in ableist and patriarchal contexts, and interrogates anger's role in "vigilante" motherhood to resist shame.

The personal voice of Gabel's piece is replicated in the first Musing of this special issue, a poem by Nitra Mishra titled "And Stigma Followed me Everywhere." Given poetry's strong power to evoke feelings, and to explore affective experiences in ways that straight-forward academic analyses cannot, this contribution is both illuminating and apt for a special issue such as this. Mishra's poem traverses racialized, gendered stigma - stigma being an affective phenomenon is related to shame in complex ways. Mishra deftly describes that awareness of being seen - of being "looked [at] in awe" and of the "gaze" that "followed" - to highlight the centrality of visual exposure both to shame and to stigma. This theme of visibility also features in the second Musing piece of the special issue. In "Gender, Shame, and the Pantsuit," Mary Edwards examines clothing and its relation to women's embodiment, shame, and being seen. True to the feminist Leitmotif on shame, Edwards notes that the sexualization of women's bodies means that they are rendered visible in specific ways. For Edwards, this "suggests that clothing could be an important trigger of shame for women, as it can fail them in ways it cannot fail men."

\section{'Gender and the Politics of Shame' and Shame Theory}

Edwards, again, draws on Bartky and on Dolezal's work on embodied shame, which itself utilizes existing work of the phenomenological tradition. ${ }^{30}$ Indeed, shame - if not gendered shame - has long been theorized by philosophers, and the authors of this special issue make ample use of such existing resources. Jean-Paul Sartre's work on 'The Look' makes an appearance, ${ }^{31}$ as does Frantz Fanon's treatment of racialized shame. ${ }^{32}$ Dan Zahavi's phenomenology of shame is drawn on, ${ }^{33}$ as is Martha

\footnotetext{
${ }^{30}$ Dolezal, The Body and Shame: Phenomenology, Feminism, and the Socially Shaped Body.

${ }^{31}$ Jean-Paul Sartre, Being and Nothingness (New York: Washington Square Press, 1992).

${ }^{32}$ Frantz Fanon, Black Skin White Masks (New York: Grove Press, 1967).

${ }^{33}$ Dan Zahavi, "Shame and the Exposed Self," in Reading Sartre: On Phenomenology and Existentialism, ed. Jonathan Webber (London: Routledge, 2010).
} 
Nussbaum's influential work on shame, disgust, and the law $;{ }^{34}$ and Lisa Guenther's contribution on the relationship between shame and humiliation..$^{35}$ Moreover, shame theorists working in disciplines other than philosophy also feature throughout this special issue. The well-known work by sociologists, Thomas Scheff ${ }^{36}$ and Erving Goffman, ${ }^{37}$ is utilized by contributors, as is the psychological treatment of shame by Silvan Tomkins (recently championed by theorists Sedgwick and Frank) ${ }^{38}$ and Helen Block Lewis. ${ }^{39}$ Sara Ahmed's influential book on the cultural politics of emotion, which includes a chapter on shame, also constitutes a critical resource for contributing authors. $^{40}$

While this list is by no means exhaustive, it highlights the fact that the articles collated here cut across disciplines and in their examination of gendered, racialized, classed, and disabled shame also work across different theoretical frameworks, including phenomenology, affect theory, queer theory, critical race theory, critical disability studies, existentialism, and literary theory, while engaging canonical work in feminism (on shame, but also on the emotions more generally). In examining what shame is, how it functions, and what its social and political implications are, authors describe and elaborate upon shame's harmful consequences, the role of visibility and exposure in the shame experience, mirroring, and shame's distinction from other feeling-states such as humiliation and guilt. Some contributions also point to positive conceptualizations of shame and to the importance of shame for our moral lives. Authors develop recommendations for how feminists should deal with shame, and the words "resistance," "overcoming," and "healing" are central to these discussions, whether an author thinks that shame must be surpassed or transcended in some way, or whether they believe shame to have inherent, transformative potential.

\section{A Twenty-first Century Feminist Shame Theory}

This special issue, then, presents a diverse set of essays that is contextually, methodologically, and theoretically rich, and that sheds light specifically on the gendered nature of shame. Although more work on shame and transnational feminism is needed, I think the special issue articles do a good job of bringing together original work on shame while highlighting important existing work in shame theory and, especially, in feminist canonical work. Much of the latter has appeared in the pages of this journal, and I am delighted that the current special issue consolidates Hypatia's engagement with gendered shame. Over the years, influential articles by Jill Locke, ${ }^{41}$

\footnotetext{
${ }^{34}$ Martha C. Nussbaum, Hiding from Humanity: Disgust, Shame, and the Law (Princeton, New Jersey: Princeton University Press, 2004).

${ }^{35}$ Lisa Guenther, "Resisting Agamben: The Biopolitics of Shame and Humiliation," Philosophy and Social Criticism 38, no. 1 (2011): 59-79.

${ }^{36}$ Thomas J. Scheff, "Shame and the Social Bond: A Sociological Theory," Sociological Theory 18, no. 1 (2000): 84-99.

${ }^{37}$ Erving Goffman, Stigma: Notes on the Management of Spoiled Identity (London: Penguin Books, 1990).

${ }^{38}$ Eve Kosofsky Sedgwick and Adam Frank, "Shame in the Cybernetic Fold: Reading Silvan Tomkins," in Touching Feeling: Affect, Pedagogy, Performativity, ed. Eve Kosofsky Sedgwick (London: Duke University Press, 2003), 93-121. Eve Kosofsky Sedgwick, Adam Frank, and Irving E. Alexander, eds., Shame and Its Sisters: A Silvan Tomkins Reader (London: Duke University Press, 1995).

${ }^{39}$ Helen Block Lewis, "Shame and the Narcissistic Personality," in The Many Faces of Shame, ed. Donald L. Nathanson (New York: The Guilford Press, 1987).

${ }^{40}$ Sara Ahmed, The Cultural Politics of Emotion (Edinburgh: Edinburgh University Press, 2004).

${ }^{41}$ Jill Locke, "Shame and the Future of Feminism," Hypatia 22, no. 4 (2007): 146-62.
} 
Erin Taylor and Laura Ebert Wallace, ${ }^{42}$ Luna Dolezal, ${ }^{43}$ Jennifer Manion,${ }^{44}$ Anne Drapkin Lyerly, ${ }^{45}$ Ellen K. Feder, ${ }^{46}$ and Ullaliina Lehtinen ${ }^{47}$ have been published by Hypatia, and the special issue should be read as a continuation of this feminist work on shame, constituting an expressly feminist shame theory for the twenty-first century that builds upon and critically extends the feminist Leitmotif of shame.

In conclusion, I want to express my thanks to the many people who supported this project. I received an overwhelming number of submissions in response to the call for papers (over 65 articles, 4 Musings, and 3 solicited book reviews), and want to thank the Hypatia editorial team, especially Sally Scholz, Miranda Pilipchuk, and Shelley Wilcox, for helping me work through these. Their professionalism and enthusiasm for the project made a sometimes daunting task manageable and enjoyable. I am also grateful to the contributing authors, who persevered throughout the review process and produced scholarship that will have lasting value for feminists working on gendered shame. Thanks is also due to the reviewers, many of whom went above and beyond the call of duty by reviewing multiple times and sometimes under considerable time constraints. Without their voluntary work a special issue of this kind would not be possible. Finally, I want to acknowledge support from my past sponsor, the British Academy, and my present funder, the European Commission for the latter's support of my Marie Skłodowska-Curie project, GENDEMOTION: The Gendered Politics of Emotion in Austerity Ireland. I wish you affectively stimulating and thought-provoking reading as you make your way through the materials of this special issue on 'Gender and the Politics of Shame.'

\section{REFERENCES}

Ahmed, Sara. The Cultural Politics of Emotion. Edinburgh: Edinburgh University Press, 2004.

Bartky, Sandra Lee. "Shame and Gender." In Femininity and Domination: Studies in the Phenomenology of Oppression, 83-98. New York: Routledge, 1990.

Beauvoir, Simone. The Second Sex. London: Vintage, 1997.

bell hooks. "Naked Without Shame: A Counter-Hegemonic Body Politic." In Talking Visions: Multicultural Feminism in a Transnational Age, edited by Ella Shohat, 65-74. New York: MIT Press, 2001.

Butler, Judith. Bodies That Matter: On the Discursive Limits of "Sex." New York: Routledge, 2014.

Clough, Patricia T. "The Affective Turn: Political Economy, Biomedia, and Bodies." In The Affect Theory Reader, edited by Melissa Gregg and Gregory J. Seigworth,

\footnotetext{
${ }^{42}$ Erin N. Taylor and Lora Ebert Wallace, "For Shame: Feminism, Breastfeeding Advocacy, and Maternal Guilt," Hypatia 27, no. 1 (2012).

${ }^{43}$ Luna Dolezal, "The (In) Visible Body: Feminism, Phenomenology, and the Case of Cosmetic

Surgery," Hypatia: A Journal of Feminist Philosophy 25, no. 2 (2010): 357-75.

${ }^{44}$ Jennifer C. Manion, "Girls Blush, Sometimes: Gender, Moral Agency, and the Problem of Shame," Hypatia: A Journal of Feminist Philosophy 18, no. 3 (2003): 21-41.

45 Anne Drapkin Lyerly, "Shame, Gender, Birth," Hypatia: A Journal of Feminist Philosophy 21, no. 1 (2006): 101-18.

${ }^{46}$ Ellen K. Feder, "Tilting the Ethical Lens: Shame, Disgust, and the Body in Question," Hypatia: A Journal of Feminist Philosophy 26, no. 3 (2011): 632-50.

${ }^{47}$ Ullaliina Lehtinen, "How Does One Know What Shame Is? Epistemology, Emotions, and Forms of Life in Juxtaposition," Hypatia: A Journal of Feminist Philosophy 13, no. 1 (1998): 56-77.
} 
206-25. London: Duke University Press, 2010.

Dolezal, Luna. "The (In) Visible Body: Feminism, Phenomenology, and the Case of

Cosmetic Surgery." Hypatia: A Journal of Feminist Philosophy 25, no. 2 (2010): 357-75.

- The Body and Shame: Phenomenology, Feminism, and the Socially Shaped Body. London: Lexington Books, 2015.

Eisler Burnett, Hannah. "Shame Game: Romance Novels and Feminist Shame, a Mad Lib for Collective Feeling." Women and Performance: A Journal of Feminist Theory 23, no. 1 (2013): 140-44.

Fanon, Frantz. Black Skin White Masks. New York: Grove Press, 1967.

Feder, Ellen K. "Tilting the Ethical Lens: Shame, Disgust, and the Body in Question." Hypatia: A Journal of Feminist Philosophy 26, no. 3 (2011): 632-50.

Ferguson, Ann, and Margaret E Toye. "Special Issue: Feminist Love Studies." Hypatia: A Journal of Feminist Philosophy 32, no. 1 (2017).

Fischer, Clara. "Feminist Philosophy, Pragmatism, and the 'Turn to Affect': A Genealogical Critique." Hypatia: A Journal of Feminist Philosophy 31, no. 4 (2016): 810-26.

- "Gender, Nation, and the Politics of Shame: Magdalen Laundries and the Institutionalisation of Feminine Transgression in Modern Ireland." Signs: Journal of Women in Culture and Society 41, no. 4 (2016): 821-43.

_. "Revealing Ireland's 'Proper' Heart: Apology, Shame, Nation." Hypatia: A Journal of Feminist Philosophy 32, no. 4 (2017): 751-67.

_. "Revisiting Feminist Matters in the Post-Linguistic Turn: John Dewey, New Materialisms, and Contemporary Feminist Thought." In New Feminist Perspectives on Embodiment, edited by Clara Fischer and Luna Dolezal. Palgrave MacMillan, 2018.

Goffman, Erving. Stigma: Notes on the Management of Spoiled Identity. London: Penguin Books, 1990.

Gregg, Melissa, and Gregory J. Seigworth, eds. The Affect Theory Reader. London: Duke University Press, 2010.

Guenther, Lisa. "Resisting Agamben: The Biopolitics of Shame and Humiliation." Philosophy and Social Criticism 38, no. 1 (2011): 59-79.

Halperin, David, and Valerie Traub, eds. Gay Shame. Chicago and London: University of Chicago Press, 2009.

Harris-Perry, Melissa V. Sister Citizen: Shame, Stereotypes, and Black Women in America. New Haven and London: Yale University Press, 2011.

Jaggar, Alison. "Love and Knowledge: Emotion in Feminist Epistemology." In Women and Reason, edited by Elizabeth D. Harvey and Kathleen Okruhlik, 11542. Ann Arbor: The University of Michigan Press, 1992.

Johnson, Liza. "Perverse Angle: Feminist Film, Queer Film, Shame." Signs: Journal of Women in Culture and Society 30, no. 1 (2004): 1361-84.

Lebron, Christopher J. The Color of Our Shame: Race and Justice in Our Time. New York: Oxford University Press, 2013.

Lehtinen, Ullaliina. "How Does One Know What Shame Is? Epistemology, Emotions, and Forms of Life in Juxtaposition." Hypatia: A Journal of Feminist Philosophy 13, no. 1 (1998): 56-77.

Lewis, Helen Block. "Shame and the Narcissistic Personality." In The Many Faces of Shame, edited by Donald L. Nathanson. New York: The Guilford Press, 1987.

Locke, Jill. Democracy and the Death of Shame: Political Equality and Social Disturbance. Cambridge University Press, 2016. 
. "Shame and the Future of Feminism." Hypatia 22, no. 4 (2007): 146-62.

Lorde, Audre. "The Uses of Anger: Women Responding to Racism.” In Sister Outsider: Essays and Speeches, 124-35. Berkeley: Crossing Press, 1984.

Lyerly, Anne Drapkin. "Shame, Gender, Birth.” Hypatia: A Journal of Feminist Philosophy 21, no. 1 (2006): 101-18.

Manion, Jennifer C. "Girls Blush, Sometimes: Gender, Moral Agency, and the Problem of Shame." Hypatia: A Journal of Feminist Philosophy 18, no. 3 (2003): 21-41.

Mann, Bonnie. Sovereign Masculinity: Gender Lessons From the War on Terror. Oxford: Oxford University Press, 2014.

Mendible, Myra, ed. American Shame: Stigma and the Body Politic. Bloomington: Indiana University Press, 2016.

Meyers, Diana Tietjens. "Emotions and Heterodox Moral Perception: An Essay in Moral Social Psychology." In Feminists Rethink the Self, edited by Diana Tietjens Meyers. Boulder, CO: Westview Press, 1997.

Munt, Sally R. Queer Attachments: The Cultural Politics of Shame. Aldershot: Ashgate, 2008.

Nussbaum, Martha C. Hiding from Humanity: Disgust, Shame, and the Law. Princeton, New Jersey: Princeton University Press, 2004.

Popa, Bogdan. Shame: A Genealogy of Queer Practices in the 19th Century. Edinburgh: Edinburgh University Press, 2017.

Probyn, Elspeth. Blush: Faces of Shame. London: University of Minnesota Press, 2005.

Sartre, Jean-Paul. Being and Nothingness. New York: Washington Square Press, 1992.

Sedgwick, Eve Kosofsky, and Adam Frank. "Shame in the Cybernetic Fold: Reading Silvan Tomkins." In Touching Feeling: Affect, Pedagogy, Performativity, edited by Eve Kosofsky Sedgwick, 93-121. London: Duke University Press, 2003.

Sedgwick, Eve Kosofsky, Adam Frank, and Irving E. Alexander, eds. Shame and Its Sisters: A Silvan Tomkins Reader. London: Duke University Press, 1995.

Spelman, Elizabeth V. "Anger and Insubordination." In Women, Knowledge, and Reality: Explorations in Feminist Philosophy, edited by Ann Garry and Marilyn Pearsall, 263-73. Boston: Unwin Hyman, 1989.

- "The Virtue of Feeling and the Feeling of Virtue." In Feminist Ethics, edited by Claudia Card, 213-32. Kansas: University of Kansas Press, 1991.

Taylor, Erin N., and Lora Ebert Wallace. "For Shame: Feminism, Breastfeeding Advocacy, and Maternal Guilt." Hypatia 27, no. 1 (2012).

Thomas J. Scheff. "Shame and the Social Bond: A Sociological Theory." Sociological Theory 18, no. 1 (2000): 84-99.

Warner, Michael. The Trouble with Normal: Sex, Politics, and the Ethics of Queer Life. Cambridge, Mass.: Harvard University Press, 2000.

Young, Iris Marion. "Menstrual Meditations." In On Female Body Experience: "Throwing Like a Girl and Other Essays." Oxford University Press, 2005.

Zahavi, Dan. "Shame and the Exposed Self." In Reading Sartre: On Phenomenology and Existentialism, edited by Jonathan Webber. London: Routledge, 2010. 